\title{
Prevalence and Awareness of Health Implications of Open Air Defecation in Yenagoa Metropolis, Bayelsa State, Nigeria
}

\author{
Amawulu $\mathrm{E}^{1 *}$, Bunsen $\mathrm{BHI}^{2}$ and Esther $\mathrm{OM}^{1}$ \\ ${ }^{1}$ Department of Biological Sciences, Niger Delta University, Nigeria \\ ${ }^{2}$ Department of Environmental Health, Ministry of Environment, Nigeria
}

*Corresponding author: Ebenezer Amawulu, Department of Biological Sciences, Niger Delta University, Wilberforce Island, Bayelsa State, Nigeria, Email: ebenezeramawulu@gmail.com

\section{Research Article \\ Volume 4 Issue 2}

Received Date: September 21, 2020

Published Date: October 23, 2020

DOI: $10.23880 /$ phoa-16000164

\section{Abstract}

Identifying the factors responsible for open air defecation practices in a location are basic pre-requisites for achieving the Sustainable Development Goal for ending open defecation. This study was undertaken to access the prevalence and socioeconomic determinant of open air defecation in Yenegoa metropolis during August, 2019 to November, 2019. Eleven communities in 150 households were mapped and identified. A minimum of 10 households from each community were randomly selected for the study. The history of open air defecation in the selected communities was asses using structured questionnaire. The questionnaire contains information on the personal characteristics, awareness and practices and implication of open air defecation. One hundred and fifty (150) questionnaires were distributed and retrieved. Fifty-three percent (53\%) of the respondents were male while $47 \%$ were female. Data collected were analyzed using descriptive statistics. From the result, the prevalence of open air defecation was $18.7 \%$. Percentages of those that own a building and those that lived in rented apartment were $60 \%$ and $40 \%$ respectively. Thirty six point six percent of the respondents in a rented apartment had no toilet facility, $10 \%$ lacked funds to own a toilet facility, $6 \%$ of the respondents lacked adequate space to erect a good toilet, $3.3 \%$ was not interested in the general toilet while $23.3 \%$ had no definite reasons. The awareness on the health implications of open air defecation was low. All respondents accepted to have suffered from one kind of infections or the other. More respondents (20\%) have had diarrhea, $18 \%$ have suffered from toilet infections while $15.3 \%, 13.3 \%$, and $12 \%$ of the respondents have suffered from Typhoid, dysentery, and worm infection respectively.

Keywords: Open Air Defeacation; Prevalence; Diseases; Awareness; Socio-Economic; Household; Yenagoa

Abbreviations: OD: Open defecation; IHME: Institute for Health Metrics and Evaluation; DALY: Disability-Adjusted Life Year; SDG: Sustainable Development Goals; UNCEF: United Nations Children's Fund.

\section{Introduction}

Open defecation (OD) is the human practice of defecating in an open field, waterway, bushes, forests, ditches, streets, canals, open trenches and other open spaces [1]. As at 2016, about 892 million people practices open defecation [2]. According to IHME [3], these figures represent seventy-six percent $(76 \%)$ of the total population in seven countries, which later increase to eleven countries across the globe in 2017. Nigeria is ranked second next to India with a total of 47 million people practicing open air defecation [4]. Over 499,000 deaths of children of under 5-years are traceable to open defecation related diseases. The Disability-Adjusted Life Year (DALY) due to open defecation is estimated at 45.1 million [3]. 
Open air defecation is strongly associated with incidence of diarrhea disease [5,6], high prevalence of helminthes infection [7], gastro- enteric diseases [8] and stunted growth in children less than five years of age $[9,10]$. There is also strong link between Open defecation and poverty especially where sanitation facilities, infrastructure and health services are not available. World Health Organization [4], reported that over 965 million people who practice open air defecation had no sanitation facility. Among which, $61 \%$ lives in rural settlement while only $10 \%$ lives in the urban settlement, the rest $29 \%$ lives in unclassified settlement [4]. In the rural settlement, $95 \%$ of the open defecators are among the poorest quintile and only $2 \%$ are of rich background. Over $35-47 \%$ of the low-income earners practices open defecation [11].

Eliminating open air defecation by the year 2030 is the target of the Sustainable Development Goals (SDG) [12]. However, the increasing rate of urbanization, have posed several health challenges on human and have jeopardized environmental healthiness of most community [1]. This is one of the major setbacks to the actualization of the Sustainable Development Goals in most community. Yenagoa metropolis is a fast growing urban Centre. The consequences are the increasing rate of open defecation and several related nuisances within the metropolitan communities. Identifying the factors responsible for open air defecation practices in a location are basic pre-requisites needed to achieve the aim of the SDG $[13,14]$. However, this information is lacking in Yenagoa Metropolis of Bayelsa State. This study is therefore undertaken to assess the prevalence and socio economic determinant of open defecation in Yenagoa Metropolis. The result of this report shall provide vital information to Government and health planner on the need to re-emphasize the necessity for community base environmental health practices.

\section{Materials and Methods}

\section{Study Area}

This study was conducted in Yenagoa metropolis $\left(4^{0} 53^{\prime} \mathrm{N}\right.$ and $5^{\circ} 17^{\prime} \mathrm{E}$ ). It is the capital city of Bayelsa State and also the head quarter of Yenagoa municipal. Details about this study location have described extensively by Ebenezer, et al. [15].

\section{Study Design}

The study adopted a community based cross sectional study among households in Yenagoa metropolis in Bayelsa State to identify households that practice open defecation and factors associated with such practice during August 2019 to November, 2019.

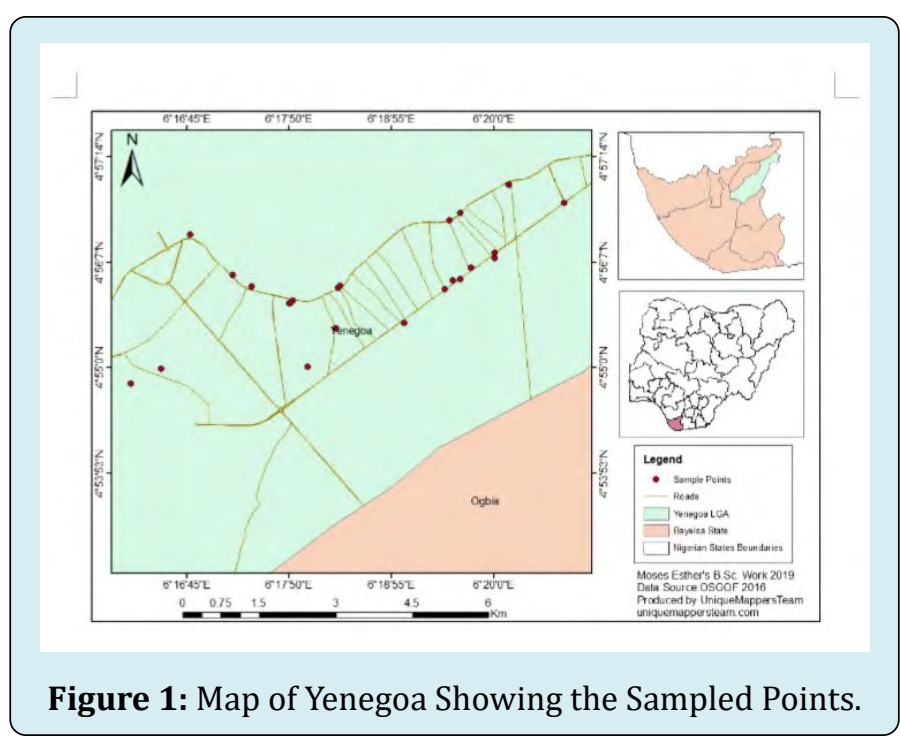

\section{Ethical Consideration}

Verbal content was obtained from community head, household head and selected individuals participants after when the purpose and benefits of the study was properly explained to them.

\section{Inclusion Criteria}

The respondents who have stayed in the village for at least one year or are willing to stay in the next one year were all included in the study.

\section{Research Instrument}

The instrument used for data collection was a structured questionnaire tag: The prevalence of open air defecation in Yenagoa metropolis, Bayelsa State. Each questionnaire comprised of two sections; A and B. Section contained demographic information of respondents. Section B contains items that illicit the response of household on their uses and availability of toilet facility in their residents.

\section{Validity of Research Instrument}

The research instrument was corrected and validated by an expert in measurement and evaluation to have satisfied the purpose for which the research was designed.

\section{Sample and Sampling Techniques}

Following the research design, a multi-stage descriptive framework, including survey, data collection, analysis and interpretation of data was planned. The first stage involves the mapping of some communities in Yenagoa metropolis based on population density. The second stage involves the selection of streets, within each of the selected residential 
neighborhoods. In accessing the implication of open defecation in Yenagoa city, the following was employed:

- Houses in residential areas with high population density that lacks proper toilet facilities was mapped

- Number of children (children below the age of five) resident in these areas was noted.

- Knowledge, attitude and social economic behavior as regarding the issue of open defecation and indiscriminate disposal of feces in form of solid waste were noted.

This survey was carried out in August, 2019 to November, 2019. A random sampling technique was employed to select 11 communities. A minimum of two streets per community was selected to obtain a primary data. Data were obtained from household of the selected houses using questionnaire. Communities selected are: Amarata, Biogbolo, Ekeki, Kpansia, Okaka, Okutukutu, Onopa, Swali, Yenagoa, Yenezueepie, Yenezue-gene. The coordinates of each community and household was recorded.

\section{Method of Data Collection}

The research data was collected through primary source. A total of 150 households were selected for the study using simple random sampling technique. One member from each household, preferably the head of the family was interviewed personally. A structured questionnaire was used to collect information regarding the personal characteristics, awareness and practices about implication of open air defecation. The questionnaires were structured to be ticked conveniently by the respondents after a relevant explanation was given on the above topic. Explanation in Pidgin English and Epie dialect was rendered for those with no formal education for a better understanding.

\section{Method of Data Analysis}

Data entry was done using Microsoft excel and analysis was done using the SPSS software version 20. Descriptive statistics were calculated for background variables using simple percentages Relationship between variables was obtained using Chi- square at confidence level of $p=0.05$.

\section{Results}

One hundred and fifty (150) questionnaires were distributed and retrieved. Fifty-three percent (53\%) of the respondents were male while $47 \%$ were female. The percentages of those who were married, single, divorced and widows was $47 \%, 30 \%, 10 \%$, and $13 \%$ respectively. The age characteristics of the respondents were 20 yrs (20\%), 21-26 yrs (13.3\%), 26-30 yrs (6.7\%), 31-35yrs (23.3\%). $10 \%$ wee within $36-40,47-45,46-50 y$ rs while $3.3 \%$ are within 56 and above of age respectively. The occupation of the respondents was farmers $(22.6 \%)$, civil servants $(22 \%)$, traders $(11.3 \%)$, accountant (4.6\%), medical personnel (1 4\%) and lecturers $(3.3 \%)$ respectively. The educational qualifications of respondents were formal education (20\%), Primary School Certificate (6.7\%), SSCE (26.6\%), B.Sc (16.7\%), M.Sc (10\%), PGDE (13.3\%), NCE/ND/HND (3.3\%) and PhD (3.3\%). Detail information is shown in Table 1.

\begin{tabular}{|c|c|c|}
\hline Variable & Frequency & Percentage \\
\hline \multicolumn{3}{|c|}{ Sex } \\
\hline Male & 80 & 53.3 \\
\hline Female & 70 & 46.7 \\
\hline \multicolumn{3}{|c|}{ Marital Status } \\
\hline Single & 45 & 30 \\
\hline Married & 70 & 47 \\
\hline Divorced & 15 & 10 \\
\hline Widow (Er) & 20 & 13 \\
\hline \multicolumn{3}{|c|}{ Age } \\
\hline$<20$ & 30 & 20 \\
\hline $21-25$ & 20 & 13.3 \\
\hline $26-30$ & 10 & 6.7 \\
\hline $31-35$ & 35 & 23.3 \\
\hline $36-40$ & 15 & 10 \\
\hline $41-45$ & 15 & 10 \\
\hline $46-50$ & 15 & 10 \\
\hline 51-55 & 5 & 3.3 \\
\hline 56 And Above & 5 & 3.3 \\
\hline \multicolumn{3}{|c|}{ Occupation } \\
\hline Medical Personnel & 6 & 4 \\
\hline Lecturer & 5 & 3.35 \\
\hline Accountant & 7 & 4.7 \\
\hline Teacher & 31 & 20.7 \\
\hline Farmer & 34 & 22.7 \\
\hline Civil Servant & 33 & 22 \\
\hline Trader & 17 & 11.3 \\
\hline Others & 17 & 11.3 \\
\hline \multicolumn{3}{|c|}{ Educational Qualification } \\
\hline Phd & 5 & 3.3 \\
\hline M.Sc & 15 & 10 \\
\hline B.Sc & 25 & 16.7 \\
\hline Pgde & 20 & 13.3 \\
\hline Nce/Nd/Hnd & 5 & 3.3 \\
\hline Ssce & 40 & 26.7 \\
\hline Fs Lc & 10 & 6.7 \\
\hline Non Educated & 30 & 20 \\
\hline
\end{tabular}

Table 1: Personal Data of Respondents. 


\section{Prevalence of Open Air Defecation in Yenagoa Metropolis during August-November, 2019}

The prevalence of open air defecation was $18.7 \%$. The prevalence of the respondents that own toilet facility at home, those that does own a toilet and those that defecate in general toilets was $60 \%, 40 \%$ and $53.3 \%$ respectively. Eleven percent (11.3\%) of the total respondents had lived in the study location for less than a year while $88.7 \%$ had lived for over a year. Detail is shown in Table 2 .

\begin{tabular}{|c|c|c|}
\hline Question & Frequency & Percentage \\
\hline \multicolumn{3}{|c|}{ Do You Use Toilet Facility At Home } \\
\hline YES & 90 & 60 \\
\hline NO & 60 & 40 \\
\hline \multicolumn{3}{|c|}{ Where Do You Use For Defecation } \\
\hline General Compound Toilet & 32 & 53.3 \\
\hline Available Open Spaces & 28 & 18.7 \\
\hline Community Toilet & 0 & 0 \\
\hline \multicolumn{3}{|c|}{ How Long Have You Been Resident In Your Locality } \\
\hline$<1 \mathrm{Yr}$ & 17 & 11.3 \\
\hline 1yr And Above & 133 & 88.7 \\
\hline
\end{tabular}

Table 2: Prevalence of Open Air Defecation in Yenagoa Metropolis during August - November, 2019.

\section{Socio Demographic Indicators and Awareness of the Health Implications of Open Air Defecation}

Sixty percent of the respondents owned a building while $40 \%$ lived in a rented apartment. Among those that live in rented apartment, $36.6 \%$ lived in a rented apartment without toilet facility, $10 \%$ lacked funds to own a toilet facility, $6 \%$ of the respondents lacked adequate space to erect a good toilet, $3.3 \%$ was not interested in the general toilet while $23.3 \%$ had no definite reasons (Table 3).

\begin{tabular}{|c|c|c|}
\hline Questions & Frequency & $\begin{array}{l}\text { Perce } \\
\text { ntage }\end{array}$ \\
\hline \multicolumn{3}{|c|}{ Do you have your own building } \\
\hline Yes & 90 & 60 \\
\hline No & 60 & 40 \\
\hline \multicolumn{3}{|c|}{$\begin{array}{c}\text { what are your reasons for using your kind of waste disposal } \\
\text { option }\end{array}$} \\
\hline Lack of fund & 6 & 10 \\
\hline No good space to erect toilet house & 6 & 10 \\
\hline Not interested because is not well kept & 2 & 3.3 \\
\hline rented apartment does not have toilet & 22 & 36.6 \\
\hline No answer & 14 & 23.3 \\
\hline
\end{tabular}

Table 3: Socio Demographic indicators of Open Air Defecation.
The awareness of the respondents on the health implications of open air defecation is shown in table 4 . Fifty-six point six percent of the respondents had limited knowledge on health implication of OAD on disease transmission. All respondents accepted to have suffered from one kind of infections or the other. More respondents (20\%) have had diarrhea, $18 \%$ have suffered from toilet infections while $15.3 \%, 13.3 \%$, and $12 \%$ of the respondents have suffered from Typhoid, dysentery, and worm infection respectively (Table 4).

\begin{tabular}{|c|c|c|}
\hline Questions & Frequency & Percentage \\
\hline Are you aware of the consequences of Open Air Defecation \\
\hline Yes & 65 & 43.3 \\
\hline No & 85 & 56.6 \\
\hline Diarrhea & 30 & 20 \\
\hline Dysentery & 20 & 13.3 \\
\hline Typhoid & 23 & 15.3 \\
\hline Worm infection & 18 & 12 \\
\hline Toilet infection & 27 & 18 \\
\hline Non & 20 & 13.3 \\
\hline No answer & 12 & 8 \\
\hline
\end{tabular}

Table 4: Awareness of the health implication of Open Air Defecation.

\section{Discussion}

The prevalence of Open Air Defecation in Yenagoa was $18.7 \%$. This result was comparable with $47.8 \%$ and $52 \%$ prevalence reported in Wa municipality in India by Osomnu, et al. [16] and 42\% in Shakur and, Ehsan [17] in Bangladesh. However, the prevalence in this present study was four folds and five folds lower than the $67 \%$ in Maharashtra by Bhardwaj, et al. [18] and 90\% in Geetha [19] in Tiruchirapalli, Tamil Nadu respectively. Several factors have been considered to have contributed to the practice of open air defecation across the globe. According to Coffey, et al. [20], a country, whose per capita income was less than $\$ 1.25$ showed the tendency of defecating in an open space and concluded that poverty could probably be associated with open defecation. Furthermore, education had shown to have played important role in the practice of open air defecation in the rural households of Benin [21]. According to WHO, the population practicing OAD seems to decline with increasing levels of education [4]. However, the predominate factors that influences people in practicing open defecation in this present study was lack of toilet in a rented apartment, lack of money and spaces to build a toilet facility. This observation agrees with the report elsewhere $[16,22]$. They both reported that where there is inadequate of toilet facility 
within a community, people were left with the option of defecating in any available spaces. In addition, Osumanu and Kosoe [23] reported that when communal toilet is in a bad state, the heat radiating out of the stench always discourages people from using it, and therefore source to defecating in an open space around. Open defecation, lack of sanitation and personal hygiene are important factors that causes the spread of various diseases in a location [24]. The individual awareness on the consequence of open air defecation in the spread of disease in this present study location was poor. The poor awareness may highlight the importance of health education in disease control and prevention. The principles and practice of environmental health policies implies that both the residents and environmental health practitioners must have a common understanding [25]. This understanding is achievable through Health education. The impact of education on open defecation is that, households with educated heads are less likely to practice open defecation than household with less educational background. Although, the study does show the correlation between educational background and open defecation practice, the proportion of the respondents with lower educational background was higher than those with no educational background. This may have contributed to the low awareness on the implication of open air defecation in disease transmission in this present study.

The poor awareness on the implication of open defecation in disease transmission may be a related to the low educational background of the respondents. From this present study, five kinds of diseases were associated with the respondents. These diseases are diarrhea, toilet infections, and Typhoid, dysentery, and helminth infections respectively. These diseases are generally refers to as the disease of the poor and spread a poor socioeconomic environment. Studies have shown that a strong correlation exists between socioeconomic status of household head and disease burdens of children [7]. These diseases recorded in this present study are a confirmation that there could be correlation between poor sanitation and spread of diseases. Similar observation [25] reported that $>88 \%$ of diarrhea incidences are associated with poor sanitation and hygiene and causes over half a million of death of children under five years of age in 2015 and about $8.55 \%$ of all under five deaths (2.22).

\section{Conclusion}

Then Prevalence of open air defecation in Yenagoa Metropolis was high. Many reasons given by respondents for practicing open air defecation in the study area were lack of money and available spaces to erect toilet houses. The lack of people's awareness on the health implications of open air defecation was high. This may have been responsible for the high exposure of the respondents to the different kinds of toilet related diseases in the study location. This is a call for prompt Public Health Intervention. It is recommended that the provision of "general compound toilet" for people who do not have home toilet, resource mobilization and identify funding mechanism for the construction of toilet in apartments and people's own building, social sanction and environmental protection campaigns, advocate for SDG6 implementation program, making available water supply for toilet use.

\section{Acknowledgement}

We appreciate the cooperation of the community head and household head for allowing this research in their domain.

\section{References}

1. WHO, UNICEF (2017) Progress on Drinking Water, Sanitation and Hygiene: 2017 Update and SD-G Baselines. World Health Organization, United Nations Children's Fund.

2. WHO, UNICEF (2014) Progress on drinking water and sanitation, Joint Monitoring Programme update 2014. World Health Organization. United Nations Children's Fund.

3. IHME (2016) GBD: Global Burden of Disease Compare 1990-2015. Institute for Health Metrics and Evaluation, University of Washington, Seattle, WA.

4. Ameyaw S, Odame FS (2017) The Menace of Open Defecation and Disease in the Nadowli-Kaleo District, Ghana. International Journal of Scientific and Research Publications 7(12): 743-749.

5. Jill W, Wenjing T, Jenny L, Forsberg B (2010) Diarrhoeal Diseases in Low-and Middle Income Countries. Open Infect Dis J 4: 113-124.

6. Taiwo OT, Sam Wobo SO, Taiwo AM (2016) Spatial Distribution of Helminth Infections in Nigeria (20052015) and the Need for Attitudinal and Behavioural Changes in the Water, Sanitation and Hygiene Interventions. Iife Journal of Science 18(4): 913-930

7. Mara D (2017) The Elimination of Open Defecation and its Adverse Health Effects: A Moral Imperative for Governments and Development Professionals. Journal of Water Sanitation and Hygiene for Development 7(1): $1-12$.

8. Spears D, Ghosh A, Cumming O (2013) Open Defecation and Childhood Stunting in India: An Ecological Analysis of New Data from 112 Districts. Plos One 8(9): e73784. 
9. Clasen T, Sophie B, Parimita R, Belen T, Melissa Bell, et al. (2014) Effectiveness of a rural sanitation programme on diarrhea, soil-transmitted helminthes infection, and child malnutrition in Odisha, India: a cluster-randomized trial. The Lancet Global Health 2(11): e645-653.

10. Odafivwotu O (2019) Open Defecation Practice and Its Implications in Sub-Saharan Africa. World Journal of Social Sciences and Humanities 5(2): 92-100.

11. OReilly K (2016) From Toilet Insecurity to Toilet Security: Creating Safe Sanitation for Women and Girls. Wiley Interdisciplinary Reviews 3(1): 19-24.

12. Tsinda A, Abbott P, Pedley S, Charles K, Adogo J, et al. (2013) Challenges to Achieving Sustainable Sanitation in Informal Settlements of Kigali, Rwanda. Int J Environ Res Public Health 10(12): 6939-6954.

13. Ebenezer A, Daworiye PS, Enaregha EB (2016) Patterns of Plasmodium falciparum malaria among pregnant women attending antenatal clinics in communities along the Epie creek, Bayelsa State, Nigeria. Annals of Biological Research 8(6): 1-5.

14. Osumanu IK, Enoch AK, Frank A (2019) Determinants of Open Defecation in the Wa Municipality of Ghana: Empirical Findings Highlighting Sociocultural and Economic Dynamics among Households. Journal of Environmental and Public Health, pp: 10.

15. Shakur MS, Ehsan MA (1993) Intestinal Parasites. A frequent association and contributing factor of loose motion in malnourished children. Bangladesh J Child Health 17(1): 10-13.

16. Bhardwaj A, Surana A, Mithra P, Singh A, Panesar S, et al. (2013) A community based cross sectional study on use of sanitary latrines in a rural setup in Maharashtra. Healthline.

17. Geeta J, Sampath KS (2014) Open Defecation: Awareness and practices of rural districts of Tamil Nadu, India Int J Sci Res 3(5): 537-539.

18. Coffey D, Gupta A, Hathi P, Khurana N, Spears D, et al. (2014) Revealed Preference for Open Defecation: Evidence from a New Survey in Rural North India. Economic \& Political Weekly 38: 1-13.

19. Abubakaar IR, Doan PL (2017) Socio-economic challenges and opportunities of urbanization in Nigeria, in Urbanization and its impact on socio-economic growth in developingragione 4(1): 89-93.

20. Routray P, Schmidt WP, Boisson S, Clasen T, Jenkins MW (2015) Socio-Cultural and Behavioral Factors Constraining Latrine Adoption in Rural Coastal Odisha: An Exploratory Qualitative Study. BMC Public Health 1(5): 880.

21. Osumanu IK, Kosoe EA (2013) Where do I answer nature's call? An Assessment of Accessibility and Utilization of Toilet Facilities in Wa, Ghana. Ghana Journal of Geography 5: 17-31.

22. Chaturvedi V, Spears D, Ghosh A, Cumming O (2013) Open Defecation and Childhood Stunting in India: An Ecological Analysis of New Data from 112 Districts. PLoS ONE 8(9): e73784.

23. Santah C (2013) Patterns of human excreta disposal in Ayikuma, Shai-Osudoku District. University of Ghana, pp: 1-182.

24. Annette P, David K, Lorna F, Jamie B (2002) Estimating the Burden of Disease from Water, Sanitation, and Hygiene at a Global Level. Environ Health Perspect 10(5): 537-542.

25. Mihrete TS, Alemie GA, Teferra AS (2014) Determinants of Childhood Diarrhea among Underfive Children in Benishangul Gumuz Regional State, North West Ethiopia. BMC Pediatr 14: 102. 